\title{
NOVO MANUAL DE CLIMATOLOGIA APLICADA
}

\author{
MARIA JoÃO ALCOFORADO ${ }^{1}$
}

Ao contrário do que se poderia pensar, a Climatologia Aplicada não é uma Ciência recente. Na Antiguidade, povos como os Egípcios, os Gregos, os Árabes, os Chineses aplicavam os conhecimentos meteorológicos e climáticos então disponíveis na organização das suas vidas e das suas actividades. Citem-se, entre muitos outros autores, Hipócrates e Ibn Khaldun, que relacionavam a natureza dos seres humanos com as condições climáticas.

"Ressuscitando" as ideias clássicas, autores como Montesquieu, em França, Kant, Ritter e Humbolt, na Alemanha, estabeleceram relações (por vezes directas e hoje consideradas simplistas) entre a natureza humana e o clima. Mencione-se, também, o "determinismo ambiental" de Ellen Churchill Semple e de Ellsworth Huntington, sem bases científicas verificadas, mas que terá tido o mérito de chamar a atenção para certos aspectos das relações entre o homem e a natureza, que mais tarde viriam a ser aprofundadas.

Com o desenvolvimento da Climatologia e a resultante consciencialização climática que, pouco a pouco, vai sendo transmitida ao grande público através dos diversos meios de comunicação social, tem vindo a ser evidenciada a vulnerabilidade da Sociedade, face à inconstância climática. O clima controla os ambientes físico, biológico e cultural, dependendo a "reacção" humana do desenvolvimento tecnológico das diferentes civilizações. No entanto, no limiar do século XXI, julgando-se o Homem liberto deste tipo de condicionalismo, uma série de acontecimentos extremos, por um lado, e retroaccções não previstas das actividades do ser humano, por outro, vieram despertar as preocupações ecológicas, esquecidas na época de grande desenvolvimento tecnológico.

Hoje em dia, tornou-se óbvio que as actividades humanas podem, inadvertidamente, modificar o ambiente climático global através da utilização de combustíveis fósseis, da emissão de gases, da produção de aerossóis e da deflorestação. Ao mesmo tempo, o ser humano tem a possibilidade de, deliberadamente, modificar o

\footnotetext{
1 Professora Associada da Faculdade de Letras, Universidade de Lisboa. Investigadora no Centro de Estudos Geográficos da Universidade de Lisboa. Centro de Estudos Geográficos, Faculdade de Letras, Cidade Universitária. 1699 LISBOA Codex. Tel: (351-1) 7965162; Fax: (351-1) 79600 63; e-mail: mjalcoforado@mail.telepac.pt.
} 
clima na escala mesoclimática, através de uma variedade de acções tendentes ao desencadeamento de chuva, à protecção contra as geadas, à dispersão de nevoeiro e à prevenção do granizo.

Fazendo o ponto sobre esta matéria, acaba de ser publicado um manual, que sintetiza conhecimentos dispersos ${ }^{2}$. Impunha-se uma actualização do tema, na sequência de outras obras afins dos anos setenta e oitenta. Segundo os editores, este livro, que se destina a estudantes universitários, pretende dar uma perspectiva global dos diversos campos de aplicação da Climatologia e salientar as interacções entre os ambientes físico e humano, num cenário dinâmico, onde as modificações climáticas estão incluídas.

Aconselha-se a leitura deste manual, seja na aquisição de formação de base, seja na busca de pistas para aprofundamento de temas particulares.

Editores e autores são especialistas, muitos de renome internacional. Os autores dos diferentes capítulos transmitem, de forma clara e sintética, informação até agora dispersa em artigos de revista, acrescentando, alguns, conclusões inéditas. Os editores consideram que os autores são representativos dos vários países, uma vez que 5 são Australianos, 4 Canadianos, 12 pertencem ao Reino Unido e 2 são ... Europeus (sic). Esta enumeração demonstra uma certa limitação, uma vez que é praticamente ignorada toda a bibliografia em língua não inglesa. Se, no conjunto, tal não é muito grave, uma vez que grande parte da produção nesta área é anglo-saxónica, ficam de fora certas obras importantes. Citem-se, a título de exemplo, as publicações de Emmanuel Le Roy Ladurie, Pierre Alexandre e de Christian Pfister sobre Climatologia Histórica, o manual "Climat et Tourisme" e a maior parte dos artigos de Jean Pierre Besancenot, assim como toda a obra de Charles Pierre Peguy, um grande defensor do carácter antropocêntrico da Climatologia.

A obra de 352 páginas está dividida em 5 partes, que se seguem a um capítulo introdutório redigido por John Hobbs, autor de um antigo manual de Climatologia Aplicada. Vale a pena confrontar as diferentes definições de Climatologia Aplicada, de carácter mais ou menos lato, segundo os diversos autores.

Na primeira parte, Climatologia Aplicada - Os "Instrumentos" da Investigação, são apresentados métodos e técnicas em 4 capítulos (cap.2 a 5): desde a colecta de dados e os tratamentos estatísticos, passando pela modelização climática e pela gestão de recursos atmosféricos.

Nos 6 capítulos da segunda parte, é tratado o tema O Clima e os Ambientes Físicos e Biológicos. É explorada a influência de climas presentes (e de prováveis climas futuros) no funcionamento dos processos e recursos hidrológicos, incluindo os glaciares, nos processos geomorfológicos, nos solos, na vegetação e nos animais. É inovadora a apresentação destas matérias num manual de Climatologia.

A relação entre o Clima e os Ambientes Culturais, ocupa a $3^{\mathrm{a}}$ parte. São considerados elementos do "Ambiente cultural" o conforto humano e a saúde (cap.12),

2 Thompson, R. D. e A. Perry ed.(1997) - Applied Climatogy.Principles and Practice, Routledge, London and New York, 352p. 
a construção e o design (cap.13), a indústria e o comércio (cap.14), os sistemas de transporte (cap.15), a agricultura e a pesca (cap.16), a silvicultura (cap.17), o recreio e o turismo (cap.18), os aspectos sociais, legais e políticos do clima (cap.19) e, finalmente, o sector energético (cap.20).

Esta parte engloba os temas mais frequentemente conotados com a Climatologia Aplicada. As diferentes dimensões dos capítulos reflectem o desenvolvimento actual do tema, patente também no número de citações bibliográficas. Assim, por exemplo, o capítulo 12 conta com 20 páginas e 119 citações, enquanto no capítulo 19 aquelas são respectivamente de 7 e de 24 . A inclusão destes capítulos menos desenvolvidos poderá constituir um incentivo para o aprofundamento da pesquisa nalguns dos temas.

As Ambiências climáticas em mutação constituem o título da $4^{\mathrm{a}}$ parte. Ao longo de 4 capítulos, são salientadas as interacções entre variações climáticas globais e clima urbano, poluição do ar e extremos climáticos, ocupando-se o autor do último capítulo das variações climáticas nos últimos 2000 anos. Fará porventura falta uma síntese actualizada e concreta sobre o controverso tema das variações climáticas, para enquadrar as oscilações ocorridas em tempo histórico, cuja posição no fim da $4^{\mathrm{a}}$ parte não parece a mais aconselhada.

Os diferentes capítulos são apresentados de forma clara, com gráficos e figuras sugestivas, que também se podem consultar a partir do índice temático (bastante completo, onde as referências a quadros e figuras se encontram em itálico). No fim de cada capítulo, uma conclusão, graficamente isolada do restante texto e que inclui referências bibliográficas, é didacticamente muito útil.

Nota-se uma certa disparidade entre os diversos textos, redigidos pelos autores com grande liberdade. Apesar disso, os editores conseguiram apresentar um manual relativamente homogéneo e de leitura agradável, com numerosos pequenos textos que fazem a ligação entre as diferentes partes e uma síntese final ("Overview”, na $5^{\text {a }}$ Parte), que guia a leitura e facilita a compreensão do texto. Como já se referiu, a extensão dos diversos capítulos varia em função da bibliografia disponível; esta é actualizada e encontra-se organizada por capítulos.

Segundo os editores, o futuro da Climatologia Aplicada dependerá muito dos diferentes utilizadores da informação climática. As suas solicitações tornar-se-ão mais exigentes e sofisticadas. O desafio, para os climatolólogos, será de desenvolver as metodologias e as técnicas que lhes permitam explorar o mercado. Consideram ainda os editores que os Serviços Meteorológicos estatais serão progressivamente, neste campo, coadjuvados por grupos privados, ansiosos de inovar e de tornar mais eficaz a apresentação de informação sobre o tempo e o clima, assim como de maximizar as oportunidades que lhes permitirão o desenvolvimento e planeamento dos ambientes naturais e humanos. 